\title{
Laboratory diagnostics of HSCT complications: immature platelets and RBCs
}

\author{
Gina Zini \\ Fondazione Policlinico Universitario A, Gemelli IRCCS - Roma, Università Cattolica del Sacro Cuore, Roma, Italy \\ Professor Gina Zini, MD, PhD, Dpt. Diagnostica per \\ E-mail: gina.zini@unicatt.it \\ immagini, Radioterapia oncologica e Ematologia, \\ Fondazione Policlinico Universitario A. Gemelli IRCCS - \\ Roma, Università Cattolica del Sacro Cuore
}

Citation: Zini G. Laboratory diagnostics of HSCT complications: immature platelets and RBCs. Cell Ther Transplant 2021; 10(1): 6-12.

\section{Summary}

HSCT is a potentially life-saving procedure, associated with complications requiring increased vigilance and monitoring. In the immediate follow-up of patients, the blood count provides precise quantitative indications upon the post-transplant course, allowing to follow haematopoietic recovery, evaluating hemoglobin values, and the numbers of platelets and white blood cells. At the present time, useful and cheap automated hematology parameters are available, in order to improve both management and follow-up of HSC transplanted patients, that are the immature reticulocyte fraction (IRF), immature platelet fraction/reticulated platelets (IPF) and red blood cell (RBC) fragments. In the presence of post-transplant recovery of erythropoiesis and thrombocytopoiesis, IRF and IPF increase in the peripheral blood correlates in real time with haematopoietic recovery. Another useful parameter in the follow-up of these patients is the number of red blood cell fragments (FRC) which can correlate with presence of shistocytes. Availability of this parameter allows to intercept in routine practice the samples that could contain schistocytes: immediate evaluation of the peripheral blood smear will confirm or not the diagnostic suspicion.

\section{Keywords}

Automated blood analysis, immature reticulocytes fraction, immature platelets fraction, red blood cell fragments, hematopoietic cell transplantation, complications.

\section{Introduction}

HSCT is a potentially life-saving procedure, often the only curative option for a variety of diseases. This procedure is, however, associated with both immediate and long-term complications requiring increased vigilance and monitoring. Some HSCT complications can result in decreased quality of life and shortened life expectancy [1].

Early HSCT complications generally occur within 100 days post HSCT. They include: oral complications/mucositis and sepsis, neutropenic fever, haemorrhagic cystitis, endothelial damage, engraftment syndrome, idiopathic pneumonia syndrome, diffuse alveolar haemorrhage, transplant-associated microangiopathy (TAM) and sinusoidal obstruction syndrome/veno-occlusive disease (SOS/VOD), infection due to compromised immune function, organ toxicity, secondary malignancy, cancer relapse, graft failure and graft rejection.
Late post-transplant complications occur $\geq 1$ year after treatment with a wide spectrum in terms of latency, intensity, reversibility, and lethality. The most frequent causes of delayed mortality are cardiac/vascular, subsequent neoplasms, infections, and pulmonary disorders. It is noteworthy that the incidence for cardiac/vascular and subsequent neoplasms continues to increase with time after HCT and does not peak before the completion of the second decade of survivorship. Timely diagnostics of hematopoiesis reconstitution is the management cornerstone in these patients.

\section{Immature subsets of RBC and plate- lets as markers of blood recovery}

At the present time, useful and cheap automated hematology parameters are available, in order to improve both management and follow-up of HSC transplanted patients. 
- Reticulocyte count

- IRF (immature reticulocytes fraction): Fig. 1A

- IPF (immature platelets fraction)/reticulated platelets: Fig. 1B

- RBC fragments.
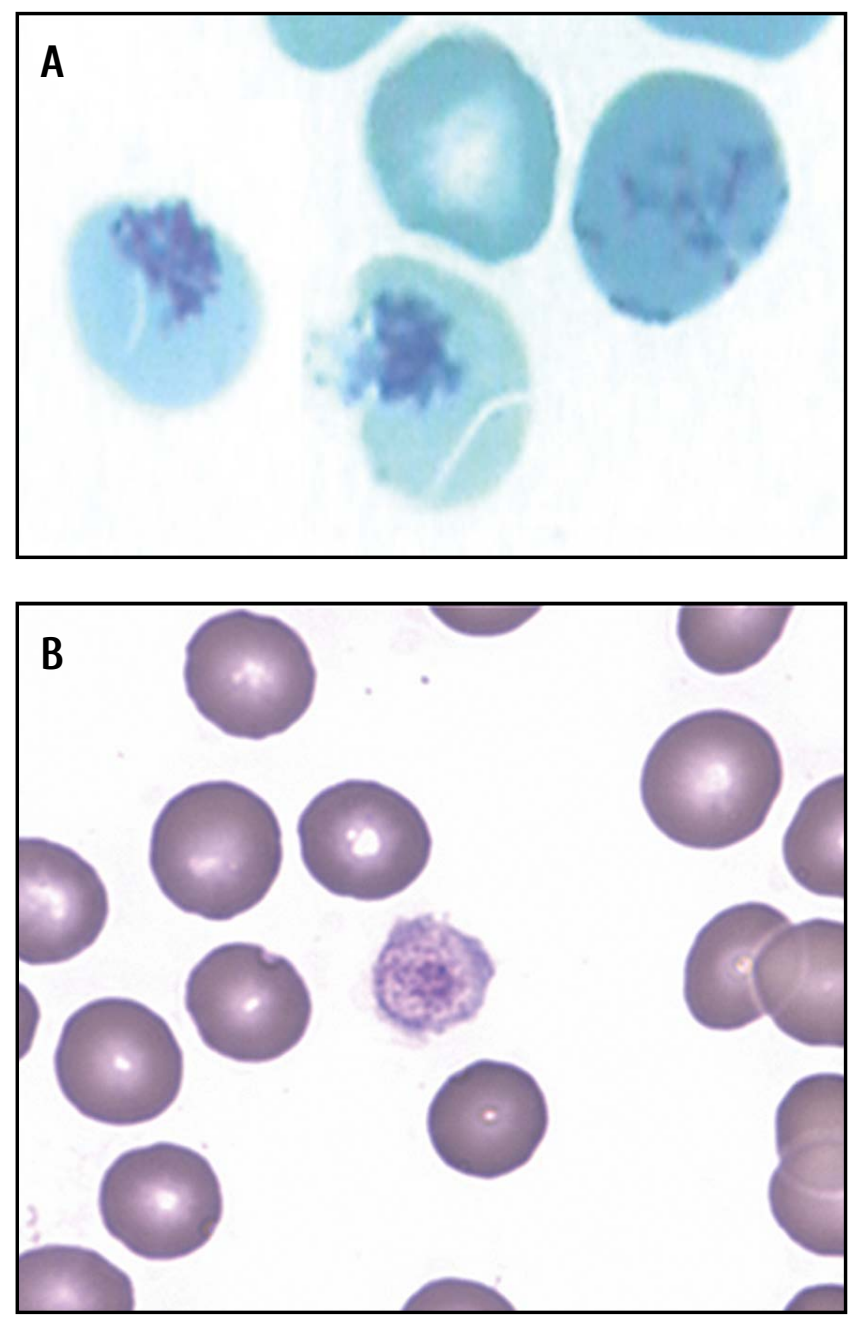

Figure 1. Immature reticulocytes $(A)$ and one reticulated platelets $(B)$ in blood smears

Reticulocytes represent the terminal stage of RBC maturation in bone marrow. Reticulocytosis rates are changed in a variety of blood disorders [2]. Immature reticulocyte fraction (IRF) arises at the late stage of erythrocyte differentiation, recognizable by trace amounts of nucleic acids seen as visible reticular substance which normally fades away within 3 days of terminal maturation. Similar reticular substance is seen in immature platelet fraction (IPF) budding from megakaryocytes in bone marrow. Following HSCT, both erythropoiesis and platelet generation proceed at much faster rates, thus exhibiting higher levels of IRF and IPF in peripheral blood.

\section{State of the art in reticulocyte count}

Reticulocyte count in the last-generation hematological analyzers correlate with the reference methods, using different staining and registration approaches:
Fluorochromes:

- ReticFit, ReticCount (thiazol orange);

- Sysmex R-1000/3000, SE 9500 (auramine O);

- Sysmex XE-2100;

- Abbott Cell Dyn 4000 (CD4K530);

- ABX Pentra (thiazol orange);

- Mindray BC-6800 (asymmetric cyanine).

Stains and light scatter/absorption:

- Bayer $\mathrm{H}^{\star 3 / A d v i a ~(o x a z i n e ~ 750) ; ~}$

- Abbott Cell Dyn 3500-3700 (NMB);

- Coulter STKS/MAXM/GEN-S (NMB);

- Microscope image analysis (Micro 21).

Constant monitoring of reticulocytes count is critical in the post-transplant period, in order to monitor engraftment and hematopoietic recovery as well as to intercept in real time changes in the erythropoiesis. Parvovirus B19 (PVB19) infection may represent such clinical situation. PVB19 is a single-stranded DNA virus of the family Parvoviridae with tropism to erythroid progenitor cells. In healthy immunocompetent individuals it causes rash of erythema infectiosum (fifth disease) in children and acute symmetric polyarthropathia in adults. Transient aplastic crisis may be induced in individuals with congenital hemolytic disorders. Persistent B19 infection in immunocompromised patients is manifested as pure red cell aplasia and chronic anemia. In peripheral blood of these patients, one may observe marked reticulocytopenia; in bone marrow, marked erythroid hypoplasia, absence of maturing precursors and presence of giant pro-erythroblasts.

Studies of immature reticulocytes (IRF) may be performed by manual or automated methods, as follows:

Morphology:

- polychromatophylic red cells;

- reticulocyte differential counts.

Flow cytometry:

- RNA content (fluorochromes, dyes);

- CD71, CD36;

- fetal hemoglobin or antigens;

- RMI = mean fluorescence-intensity (i.e., mean channel);

- Fraction(s) of RNA-rich reticulocytes:

- single thresholds (IRF);

- two thresholds (H, M, L).

Worth of note, reference intervals and diagnostic cutoff values are dependent on the methodology used.

In previous studies, a very early increase of highly fluorescent reticulocytes was shown in peripheral blood after stem cell mobilization for stem cell harvests [3]. Similar peak in immature reticulocytes is observed at the very onset of hematopoiesis recovery post-HSCT [4], as seen in Fig. 2.

Several studies have confirmed the role of the IRF as early markers in predicting hematopoietic engraftment [5-8]. 


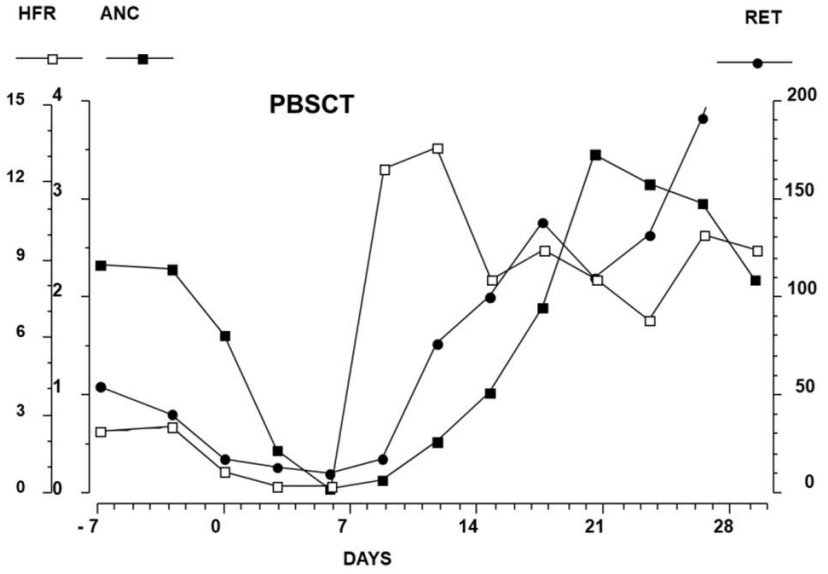

Figure 2. Dynamics of immature (higly-fluorescent) reticulocytes following PBSCT, adapted from [4]

\section{Thrombocytopoiesis}

The most relevant facts were summarized by Wang, Zheng [9]. A common scheme of thrombopoirsis is shown in Fig. 3.

- A healthy human produces approximately 1-2 million platelets per second.

- In response to thrombocytopenia, platelet production can be accelerated by up to a 10 -fold increase.

- MGKs may form platelet ribbons into blood vessels. The ribbons are formed via pseudopodia and they are able to continuously emit platelets into circulation.

- Platelets are released from the megakaryocyte cytoplasm, they still contain a small amount of RNA.

- They represent the youngest platelets in the circulation and are named reticulated or immature platelets that are not necessarily large platelets.

- When correlated with megakaryocyte, their concentration in BM is 2-3 times higher than in PB.

- Platelets persist in the circulation for 7-10 days, immature PLT have a much shorter lifespan ( $<1$ day).

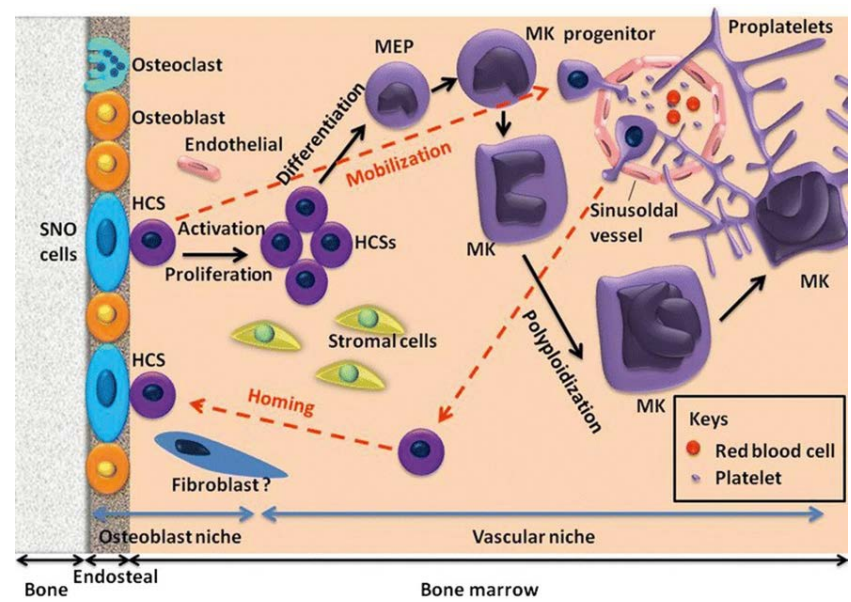

Figure 3. General view on thrombocyte production by megakaryocytes (MK), and their maturation [9]

\section{RetPlt/IPF Reference ranges}

It should be noted that flow cytometric assay of immature RBC and platelet forms yields sufficient scatter of reference values reported to range between $1 \%$ and $15 \%$, due to lack of standardization. IPF ranges in normal state differ among published studies, due to differences in counting methods (Fig. 4). Normal reference ranges are reported to range between $1 \%$ and $15 \%$. Our personal published data showed a range of $2.39 \%(0.8-5.1 \%)$. Several papers within the next 10 years have shown associations between RetPlt/IPF and such disordrs as thrombocytopenia, thrombocytosis, hereditary platelet diseases, after HSCT, thrombo-embolic disorders, kidney disease, preeclampsia, hyperthyroidism, infections and in healthy and thrombocytopenic neonates. An overall conclusion may be drawn as follows: retPLT/IPF in blood (Fig. 4) represent a useful non-invasive marker of megakaryopoietic activity in the bone marrow.

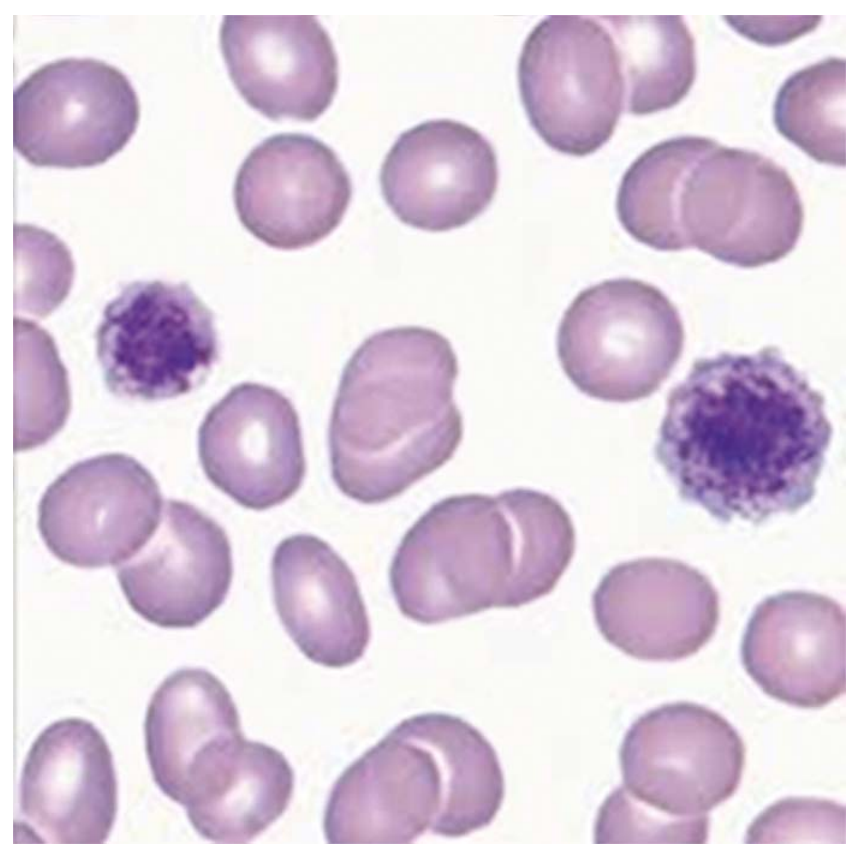

Figure 4. Immature platelets in blood film

In the literature, IPF was confirmed as one of the earliest predictors of hematopoietic recovery following peripheral blood HPC transplantation [10]. Six patients with primary diagnosis of AML or NHL were subjected to HSCT. Increased percentage of immature platelets in peripheral blood was revealed early post-transplant. According to later studies by several groups, a general consensus with rare contrary opinions exists on the role of the IPF as a useful non-invasive marker predicting hematopoietic engraftment [11-14]. An interesting association was also found between IPF ratios and bacterial nosocomial infections [15].

\section{Erythrocyte schistocytosis}

Schistocytosis in peripheral blood is another important marker revealed in the posttransplant period. Schistocytes are fragmented red blood cells (FRBC) formed in peripheral blood $(\mathrm{PB})$ as a consequence of a mechanical damage. 
These abnormal red blood cells assume a triangular, helmet-shaped form, with two or three pointed extremities. The most frequent cause of erythrocyte fragmentation is the formation of thrombi in the microvasculature as in thrombotic microangiopathies (TMA), with consumption of fibrin and platelets. RBC fragmentation occurs after the passage of erythrocytes through the fibrin cords of microthrombi. For decades, this RBC anomaly is considered a good TMA marker [16].

The present consensus on schistocyte morphology is as follows (Fig. 5):

Helmet shape: decreased size (surface/area), irregular shape, with a defective amputated zone highlighted by a rectilinear border ending with usually 2 ( 1 or 3 possible) angulated spicules. Pale central zone is not observed.

Triangular shape: reduced size, irregular shape with a defective amputated zone highlighted by a rectilinear sometimes spiculated border, ending with 2 angulated spicules. Pale central zone is not observed.

Bitten erythrocyte: Normal size, shape irregular with a defective amputated zone.

Fragments: Small/very small size, highly irregular shape.

Microspherocytes: Small size, round shape, hyperdensity (increased staining)

Irregularly contracted cells: Small size, hyperdensity, irregular outline sometimes with small protrusions and Heinz bodies.

The following literature reference values for schistocytosis (blood smears, pro mille counts) are:

- for adults: $\leq 0.1 \%$;

- for newborns: 0.3-1.9\%;

- for preterm infants: $\leq 5.5 \%$.

Appropriate guidelines for identification, counting and clinical interpretation of schistocytes were published by Zini et al. [17]. This recommendation was cited in 93 papers. Most of them did confirm the utility of the Recommendation. Papers questionnaire-based highlight its role in reducing the intra- and inter-laboratories variability of schistocyte identification and enumeration at microscope. Several published papers are focused on transplanted patients. Some studies are focused on the correlation with instrumental flags, count and/or digital RBC morphology. The latest study concerned inter-laboratory reproducibility of schistocytosis counts [18]. In conclusion, the survey identified the need for the standardization of TA-TMA morphological diagnosis, in order to optimize general diagnostic criteria (Table 1).

To confirm the morphologic rules in schistocyte identification.

- To provide common rules for laboratory staff to check at microscope the samples with flags for "fragments" and/or images from digitized systems.

- To mention new published data not only in the clinical setting of TTP.

- To implement it providing reference values in post BMT patients in collaboration with Prof. G.W. Basak, Chairman of the EBMT TCWP.

There are different methods for automated red cell fragments counts proposed by several manufacturers. E.g., Vcoulter approach based in classical flow cytometry. ADVIA 2120 method offers integrated analysis of RBC and platelet count: events with an object volume smaller than $30 \mathrm{fL}$ and with a refractive index greater than 1.4 frequence of events above the threshold of $10.000 / \mu \mathrm{L}$. Mindray BC 6800 method considers microcytic/fragmented RBCs or large platelets. Abbott Sapphire method detects RBC- specific (CD235a) and platelet-specific (CD61) surface antigensantigens to identify abnormal cell populations.

\section{Schistocytes, RBC fragments and Laws of thought: three Aristotle's axioms}

1. Contradiction/self-evident proposition: Schistocytes are red blood cell fragments (RBCFr)

2. Exclusion middle/third: Schistocytes are RBCFr identified by a peculiar shape

3. Identity (non-identity): Not all red blood cell fragments are schistocytes.

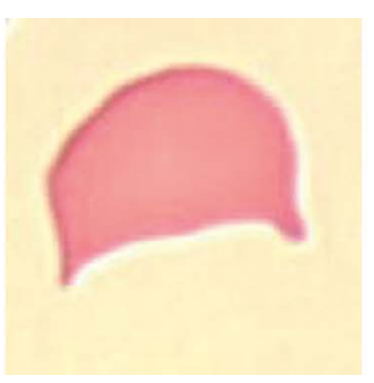

A

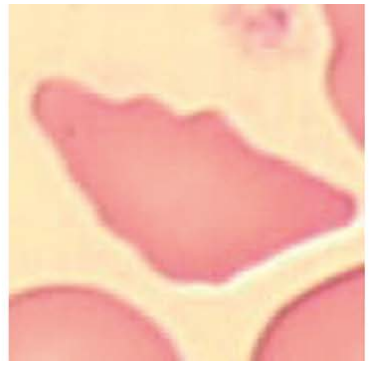

B

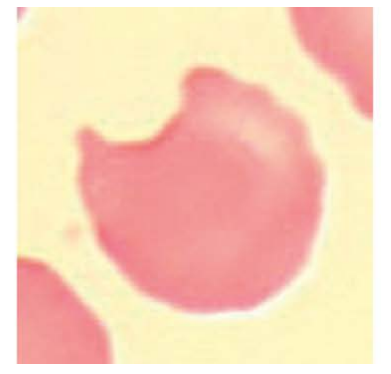

C

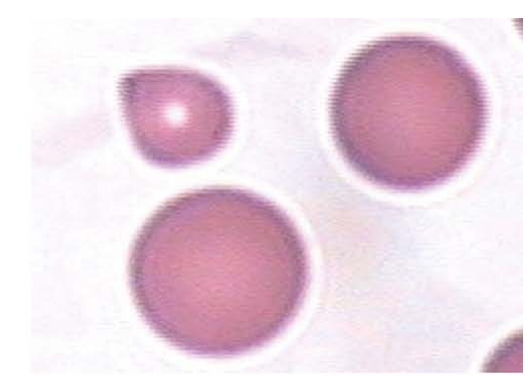

D

Figure 5. Morphological anomalies associated with schistocytosis: Helmet shape (A); triangle cells (B); bitten RBC (C); microspherocyte (D) 
Table 1. Comparison of diagnostic criteria for TMA from different sources

\begin{tabular}{|c|c|c|c|c|}
\hline $\begin{array}{l}\text { Tissue biopsy } \\
\text { confirming } \\
\text { microangiopathy } \\
\text { or criteria below }\end{array}$ & $\begin{array}{l}\text { Blood and Marrow Transplant } \\
\text { Clinical Trials Network } \\
\text { Toxicity Committee consen- } \\
\text { sus definition for TMA [19] }\end{array}$ & $\begin{array}{l}\text { International Working } \\
\text { Group Definition for } \\
\text { TMA [20] }\end{array}$ & Probable TMA [21] & $\begin{array}{l}\text { Diagnostic Criteria } \\
\text { for TA-TMA [22] }\end{array}$ \\
\hline 1 & $\begin{array}{l}\text { Peripheral blood smear with } \\
\text { RBC fragmentation and }>2 \\
\text { schistocytes per high-power } \\
\text { field }\end{array}$ & $\begin{array}{l}>4 \% \text { schistocytes in } \\
\text { peripheral blood }\end{array}$ & $\begin{array}{l}>4 \% \text { schistocytes in } \\
\text { peripheral blood }\end{array}$ & $\begin{array}{l}\text { LDH above Upper Limit of } \\
\text { Normal (ULN) }\end{array}$ \\
\hline 2 & Concurrent increase in LDH & $\begin{array}{l}\text { Thrombocytopenia } \\
<50 \times 10^{9} / \mathrm{L} \text { or decrease } \\
\text { of } 50 \% \text { from baseline }\end{array}$ & $\begin{array}{l}\text { Concurrent increase } \\
\text { in LDH }\end{array}$ & $\begin{array}{l}\text { Proteinuria on random } \\
\text { analysis with }>30 \mathrm{mg} / \mathrm{dL}\end{array}$ \\
\hline 3 & $\begin{array}{l}\text { Concurrent renal dysfunction } \\
\text { (doubling of serum creatinine } \\
\text { from baseline) and/or neu- } \\
\text { rologic dysfunction without } \\
\text { other explanations }\end{array}$ & $\begin{array}{l}\text { Sudden and persistent } \\
\text { increase in LDH }\end{array}$ & $\begin{array}{l}\text { Thrombocytopenia } \\
<50 \times 10^{9} / \mathrm{L}\end{array}$ & Hypertension \\
\hline 4 & $\begin{array}{l}\text { Negative direct and indirect } \\
\text { antiglobulin tests (DAT and IAT) }\end{array}$ & $\begin{array}{l}\text { Decrease in Hb concen- } \\
\text { tration, or increase in } \\
\text { RBC transfusion require- } \\
\text { ment }\end{array}$ & Negative DAT and IAT & $\begin{array}{l}\text { Thrombocytopenia }<50 \times 10^{9} / \mathrm{L} \text {, } \\
\text { or decrease of } 50 \% \text { from } \\
\text { baseline }\end{array}$ \\
\hline 5 & & $\begin{array}{l}\text { Decrease in serum } \\
\text { haptoglobin }\end{array}$ & $\begin{array}{l}\text { Decrease in serum } \\
\text { haptoglobin }\end{array}$ & $\begin{array}{l}\text { Hb below the Lower Limit of } \\
\text { Normal (LLN) or anaemia with } \\
\text { transfusion requirement }\end{array}$ \\
\hline 6 & & & $\begin{array}{l}\text { Absence of coagulo- } \\
\text { pathy }\end{array}$ & $\begin{array}{l}\text { Schistocytes in peripheral } \\
\text { blood or microangiopathy on } \\
\text { tissue specimen }\end{array}$ \\
\hline \multirow[t]{3}{*}{7} & & & & sC5b-9 above ULN \\
\hline & & & & $\begin{array}{l}\text { 1+2+3: Consider diagnosis of } \\
\text { TMA and monitor very closely }\end{array}$ \\
\hline & & & & $\begin{array}{l}2+7 \text { : If present at diagnosis, } \\
\text { poor outcome is apprehended. } \\
\text { Consider active treatment }\end{array}$ \\
\hline
\end{tabular}

There is a number of studies which show some differences in FRBC numbers upon manual $v s$ automatical counting. E.g., Banno et al. [23] have shown that the RBC fragments determined visually was higher than that determined by XE-2100 hematology analyzer, suggesting over-estimation of the FRBC counts by visual microscopy. Similar comparative aspects were considered in the study by Lesesve et al. [24]. In summary, automated FRC count $v s$ schistocytes visual count lead to the conclusion that not all automated red cell fragments are schistocytes.

\section{Conflict of interest}

No conflicts of interest reported.

\section{References}

1. Styczynski J, Tridello G., Koster L, Iacobelli S, van Biezen A, van der Werf S, Mikulska M, Gil L, Cordonnier C, Ljungman P, et al. Death after hematopoietic stem cell transplantation: changes over calendar year time, infections and associated factors. Bone Marrow Transplant. 2020; 55:126-136. doi: 10.1038/s41409-019-0624-Z.
2. d'Onofrio G, Kuse R, Foures C, Jou JM, Pradella M, Zini G. Reticulocytes in haematological disorders. Clin Lab Haematol. 1996; 18(Suppl 1):29-34. PMID: 9054716.

3. Remacha AF, Martino R, Sureda A, Sarda M, Solá C, Tugues D, Amill B, García J, Oliver A. Changes in the reticulocyte fraction during peripheral stem cell harvesting: role in monitoring stem cell collection. Bone Marrow Transplant 1996;17(2):163-168. PMID: 8640161.

4. Sica S, Salutari P, Laurenti L, Ortu La Barbera E, Zini G, d'Onofrio G, Serafin R, Leone G. Highly fluorescent reticulocytes after CD34+ peripheral blood progenitor cell transplantation. Bone Marrow Transplant. 1998; 21:361-364. doi: $\underline{10.1038 / \text { sj.bmt.1701098. }}$.

5. George P, Wyre RM, Bruty SJ, Sweetenham JW, Duncombe AS. Automated immature reticulocyte counts are early markers of engraftment following autologous PBSC transplantation in patients with lymphoma. J Hematother Stem Cell Res. 2000; 9(2): 219-223. doi: 10.1089/152581600319432.

6. Lesesve JF, Lenormand B, Lacombe F. The role of high fluorescent reticulocytes in monitoring Platelet generation in vivo and in vitro the aplasia outcome and optimizing the timing of peripheral blood stem cell harvesting. 
J Hematother Stem Cell Res. 2002; 11(6):987-989. doi: $10.1089 / 152581602321080664$.

7. Grazziuti ML, Dong L, Miceli MH, Cottler-Fox M, Krishna SG, Fassas A, van Rhee F, Barlogie BM, Anaissie EJ. Recovery from neutropenia can be predicted by he immature reticulocyte fraction several days before neutrophil recovery in autologous stem cell transplant recipients. Bone Marrow Transplant. 2006; 37: 403-409. doi: 10.1038/sj.bmt.1705251.

8. Molina JR, Sanchez-Garcia J, Torres A, Alvarez MA, Serrano J, Casano J, Gomez P, Martinez F, Rodriguez A, Martin C. Reticulocyte maturation parameters are reliable early predictors of hematopoietic engraftment after allogeneic stem cell transplantation. Biol Blood Marrow Transplant. 2007; 13: 172-182. doi:10.1016/j.bbmt.2006.09.007.

9. Wang B, Zheng J. Platelet generation in vivo and in vitro. SpringerPlus. 2016. 5:787. doi: 10.1186/s40064-016-2384-1.

10. Zucker ML, Murphy CA, Rachel JM, Martinez GA, Abhyankar S, McGuirk JP, Reid KJ, Plapp FV. Immature platelet fraction as a predictor of platelet recovery following hematopoietic progenitor cell transplantation. Lab Hematol 2006;12(3):125-130. doi: 10.1532/LH96.06012.

11. Briggs C, Hart D, Kunka S, Oguni S, Machin SJ. Immature platelet fraction measurement: a future guide to platelet transfusion requirement after haematopoietic stem cell transplantation. Transfusion Medicine. 2006; 16(2):101-109. doi: 10.1111/j.1365-3148.2006.00654.x.

12. Goncalo AP, Barbosa IL, Campiho F, Campos A, Mendes C. Predictive value of immature reticulocyte and platelet fractions in hematopoietic recovery of allograft patients. Transplant Proc. 2011; 43(1):241-243. doi: 10.1016/j. transproceed.2010.12.030.

13. Morkis IVC, Farias MG, Rigoni LDC, Scotti L, Gregianin LJ, Daudt LE, LM Da R Silla LM, Paz AA. Assessment of immature platelet fraction and immature reticulocyte fraction as predictors of engraftment after hematopoietic stem cell transplantation. Int J Lab Hem. 2015; 37: 259-264. doi: $\underline{10.1111 / \text { ijlh.12278. }}$

14. Meintker L, Fritsch JD, Ringwald J, Krause SW. Immature platelets do reliably predict platelet recovery in patients with intensive chemotherapy or stem cell transplantation. Vox Sang. 2017; 112(2):132-139. doi: 10.1111/vox.12483.

15. Di Mario A, Garzia M, Leone F, Arcangeli A, Pagano L, Zini G. Immature platelet fraction (IPF) in hospitalized patients with neutrophilia and suspected bacterial infection. J Infect. 2009; 59(3):201-216. doi: 10.1016/j.jinf.2009.07.007.

16. Bessis M. Blood Smears Reinterpreted. Springer-Verlag, 1977.

17. Zini G, d'Onofrio G, Briggs C, Erber W, Jou JM, Lee SH, McFadden S, Vives-Corrons JL, Yutaka N, Lesesve JF. ICSH recommendations for identification, diagnostic value and quantitation of schistocytes. Int J Lab Hematol. 2011; 34(2):107-116. DOI: 10.1111/j.1751-553X.2011.01380.x.

18. Moiseev IS, Tsvetkova T, Aljurf M, Alnounou RM, Bogardt J, Chalandon, Y, Drokov M Yu, Dvirnyk V, Faraci M, Friis LS, et al. Clinical and morphological practices in the diagnosis of transplant-associated microangiopathy: a study on behalf of Transplant Complications Working Party of the EBMT. Bone Marrow Transplant. 2019; 54:1022-1028. doi: 10.1038/s41409-018-0374-3.

19. Ho VT, Cutler C, Carter S, Martin P, Adams R, Horowitz M, Ferrara J, Soiffer R, Giralt S. Blood and marrow transplant clinical trials network toxicity committee consensus summary: thrombotic microangiopathy after hematopoietic stem cell transplantation. Biol Blood Marrow Transplant. 2005;11(8):571-575. doi: 10.1016/j.bbmt.2005.06.001.

20. Ruutu T, Barosi G, Benjamin R, Clark R, George J, Gratwohl A, Holler E, Iacobelli M, Kentouche K, Lämmle B et al. Diagnostic criteria for hematopoietic stem cell transplant-associated microangiopathy: Results of a consensus process by an International Working Group. 2007. Haematologica; 92(1):95-100. doi: 10.3324/haematol.10699.

21. Cho BS, Yahng SA, Lee SE, Eom KS, Kim YJ, Kim HJ, Lee S, Min CK, Cho SG, Kim DW et al. Validation of recently proposed consensus criteria for thrombotic microangiopathy after allogeneic hematopoietic stem-cell transplantation. Transplantation. 2010; 90(8):918-926. doi: 10.1097/ TP.0b013e3181f24e8d.

22. Jodele S, Laskin BL, Dandoy CE, Myers KC, El-Bietar J, Davies SM, Goebel J, Dixon BP. A new paradigm: Diagnosis and management of HSCT-associated thrombotic microangiopathy as multi-system endothelial injury. Blood Rev 2015;29(3):191-204. doi:10.1016/j.blre.2014.11.001.

23. Banno S, Ito Y, Tanaka C, Hori T, Fujimoto K, Suzuki T, Hashimoto T, Ueda R, Mizokami M. Quantification of red blood cell fragmentation by the automated hematology analyzer XE-2100 in patients with living donor liver transplantation. Clin Lab Haematol. 2005; 27(5):292-296. doi: 10.1111/j.1365-2257.2005.00704.x.

24. Lesesve JF, Asnafi V, Braun F, Zini G. Fragmented red blood cells automated measurement is a useful parameter to exclude shisticytes on the blood film. Int J Lab Hematol. 2012; 34(6):566-576. doi: 10.1111/j.1751-553X.2012.01434.X. 


\section{Лабораторная диагностика осложнений трансплантации гемопоэтических клеток: незрелые тромбоциты и эритроциты}

\section{Джина Зини}

Отдел визуальной диагностики, онкологической радиотерапии и гематологии, Университетская поликлиника «Гемелли», Католический Университет Сакро Куоре, Рим, Италия

\section{Резюме}

Трансплантация гемопоэтических стволовых клеток (ТГСК) является потенциально жизнеспасающей процедурой, ассоциированной с осложнениями, которые требуют повышенного внимания и мониторинга. При непосредственном динамическом наблюдении за пациентом, подсчет клеток крови обеспечивает точные количественные показания о течении посттрансплантационного периода, что позволяет отслеживать восстановление гемопоэза, уровни гемоглобина, число тромбоцитов и лейкоцитов. В настоящее время доступны полезные и дешевые автоматизированные гематологические методы для того, чтобы улучшить ведение и наблюдение пациентов после ТГСК. Это - незрелая фракция ретикулоцитов (IRF), незрелые тромбоциты/ретикулярные тромбоциты (IPF) и фрагменты эритроцитов. В процессе посттрансплантационного восстановления эритро- и тромбоцитопоэза, отмечается повышение IRF и IPF в периферической крови, что коррелирует во времени реконституцией гемопоэза.
Другим полезным параметром при ведении этих больных является число фрагментов эритроцитов, которые могут коррелировать с присутствием шистоцитов. Доступность этого параметра позволяет выявлять в рутинной практике те образцы, которые могут содержать шистоциты: немедленное исследование мазка периферической крови подтверждает (или нет) диагностическую гипотезу.

\section{Ключевые слова}

Автоматический анализ крови, фракция незрелых ретикулоцитов, фракция незрелых тромбоцитов, эритроцитарные фрагменты, трансплантация гемопоэтических клеток, осложнения. 